\begin{tabular}{|c|c|}
\hline & Asian Social Work Journal (ASWJ) \\
\hline $\begin{array}{c}\text { ASIAN SOCIAL WORK } \\
\text { JOURAL } \\
\text { (ASW) }\end{array}$ & Volume 4, Issue 1, February 2019 \\
& e-ISSN : 0128-1577 \\
& Journal home page: \\
& www.msocialwork.com \\
\hline
\end{tabular}

\title{
Transformational Leadership Directly and Indirectly Effect on Nurse Performance: Organizational Cultural as Intervening Variables
}

\author{
Nur Hidayah¹, Eva Nur Fadila² \\ 1Universitas Muhammadiyah Yogyakarta, Indonesia \\ 1Rumah Sakit PKU Muhammadiyah Gamping, Yogyakarta, Indonesia \\ Corrrespondence: Nur Hidayah (nurhidayah@umy.ac.id)
}

\begin{abstract}
A nurse performance greatly determines the quality of health services in a hospital. The purpose of this study was to prove the influence of transformational leadership on nurse performances, both directly and indirectly through organizational culture and work motivation. The research method used was a quantitative approach with cross-sectional design. The number of samples consisted of 86 nurses in a private hospital. Data collection used a questionnaire. Data analysis techniques used Partial Least Square Structural Equation Modeling (PLS-SEM). Research results shew that transformational leadership had a positive and significant effect on nurse performance both directly and indirectly through organizational culture and work motivation). The study results have shown that Transformational Leadership is effect on Organizational Culture. Transformational Leadership is effect on Work Motivation. Transformational Leadership, Organizational Culture, and Work Motivation are effect on Nurses Performance. Organizational culture mediated the effect of the transformational leadership on performance.
\end{abstract}

Key words: nurse, leadership, organizational, motivation, perfomances

\section{Introduction}

Nurse performance greatly determines the success of a hospital in dynamic environment of industry. Nurses are the largest number of health workers in the hospital and they provide services to patients 24 hours a day. Nurse performance is influenced by several factors, including leadership, organizational cultural, and work motivation of the employee. Transformational leadership is needed to shape the organizational culture and motivate the employees so that performance continues to increase.

There have been many studies in various countries about how transformational leadership creates organizational culture effectively and motivates employees to improve their performance. Based on Bass' theory, the component of transformational leadership consists of Idealized Influence (Charisma), Inspirational Motivation, Intellectual Stimulation, and Individualized Consideration (Bass, 1997). Many current researchers still use Bass' theory. Orabi found that 81.6 percent of organizational performance was influenced by inspirational motivation, intellectual stimulation, and individual consideration. Idealized influence was no effect on this outcome (Orabi, 2016). There was significant relationship between transformational leadership and employee motivation (Ahmad, Abbas, Latif, \& Rasheed, 2014). Transformational leadership also associated with work performance (Cavazotte, Moreno, \& Bernardo, 2013). Transformational leadership had significance effect on employee working 
performance (Kala'Lembang \& Soetjipto, 2015). Research by Tobing and Syaiful found that organizational cultural and work motivation had significant effect on employee performance, but transformational leadership and work motivation had no effect on employee performance (Tobing \& Syaiful, 2016). Other research resulted found to the contrary, work motivation had significan effect on employee performance (Prabowo, Noermijati, and Irawanto, 2018). Employee performance was influenced by leadership Style, organizational cultural, and employee motivation (Syafii, Thoyib, Nimran, \& Djumahir, 2015). So, there are much studies about influence of transformational leadership, organizational cultural and work motivation on employee performance in business organization that profit oriented. The study is still rare in non-profit organization, especially in hospital setting.

The aims of current study were to analyze the influence of transformational leadership, organizational culture and work motivation on the employee performance in a private hospital in Yogyakarta. In the study, organizational cultural and work motivation as mediated variable between transformational leadership and employee performance.

\section{Hypothesis (H):}

H1: Transformational Leadership has positive effect on Organizational Cultural

H2: Transformational Leadership has positive effect on Work Motivation

H3: Transformational Leadership has positive effect on Employee Performance

H4: Organizational Culture has positive and significant effect on Employee Performance

H5: Work Motivation has positive effect on Employee Performance.

H6: Organizational Cultural is mediating variable between Transformational Leadership and Employee Performance

H7: Work Motivation is mediating variable between Transformational Leadership and Employee Performance

\section{Research Method}

This research used the quantitative method with cross sectional design. Sampling technic took total sampling. The samples were 83 nurses of inpatient wards in a Private Hospital, Yogyakarta. The Data analysis used Partial Least Square (PLS) an alternative of Structural Equation Modelling (SEM). Data collection employed questioners that valid and reliable.

\section{Results}

There are 86 respondents of the research. The classification of them are $48 \%$ females, $42 \%$ males and most of them are 30-40 years old. It shows that most of them are in a productive stage. Based on the educational background, respondents with bachelor degree are $36 \%$ and the diploma degree are $64 \%$. Based on the length of work, respondents with 1-3 years of work experience are $43 \%, 21 \%$ had worked less than a year and $18 \%$ had worked less than five years. Table 1 show the characteristic of respondents.

Table 1 The Characteristic of Respondents

\begin{tabular}{lcc}
\hline \multicolumn{1}{c}{ Variabel } & Percentile \\
\hline Genders & \\
Female & $58 \%$ \\
Male & $42 \%$ \\
Ages & \\
$20-30$ year & $21 \%$ \\
$30-40$ year & $48 \%$ \\
$>40$ year & $31 \%$
\end{tabular}




\section{Education Levels}

Diploma (D3) $\quad 64 \%$

Bachelor (S1) 36\%

Length of Work

$<1$ year

$21 \%$

$1-3$ years $\quad 43 \%$

$3-5$ years $\quad 18 \%$

$>5$ years $18 \%$

\section{Validity Test}

The result of validity test of transformational leadership (TL) (13 item), organizational cultura (OC) (9 item), work motivation (WM) (10 item), and employee performance (EP) (11 item) were valid. See Table 2.

Table 2. The Result of Validity Test

\begin{tabular}{lcccc}
\hline Variable & $\begin{array}{c}\text { Items } \\
\text { Valid }\end{array}$ & $\begin{array}{c}\text { Item not } \\
\text { Valid }\end{array}$ & $\begin{array}{c}\text { Interval Corrected } \\
\text { item }- \text { total Correlation }\end{array}$ & R table \\
\hline$T L$ & 13 & 1 & $0,487-0,862$ & 0,361 \\
$O C$ & 9 & 1 & $0,547-0,912$ & 0,361 \\
$W M$ & 10 & 2 & $0,486-0,732$ & 0,361 \\
$E P$ & 11 & 0 & $0,494-0,882$ & 0,361 \\
\hline
\end{tabular}

\section{Reliability Test}

The result of reliability test of TL, OC, WM, and EP $>0,6$, so all variable were reliable See Table 3 .

Table 3. The Result of Reliability Test

\begin{tabular}{lcc}
\hline \multicolumn{1}{c}{ Variable } & Crombachs Alpha & Reliability \\
\hline Transformational Leadership $(T L)$ & 0,901 & reliable \\
Organizational Culture $(O C)$ & 0,850 & reliable \\
Work Motivation $(W M)$ & 0,849 & reliable \\
Employee Performance $(E P)$ & 0,933 & reliable \\
\hline
\end{tabular}

\section{Descriptive Analysis}

The results showed that most of nurses (employee) had high perception toward the transformational leadership. Nurses perceptions toward organizational culture in this hospital were tend to be good. Most nurses had high work motivations. The descriptive analysis results show that most nurses have a good performance, nurses have been able to work well either work individually or work in groups.

\section{Outer Model (Measurement Model)}

The results of PLS analysis can be used to test the research hypothesis. If all the indicators in the PLS model meet the requirements of convergent validity, discriminant validity and composite reliability.

Convergent validity test was done by looking at the value of the loading factor of each indicator towards the construct. This study was a confirmatory study, the loading factor limit used to test the convergence validity of each indicator was 0.7 . 
Based on the model estimation results, all indicators have a loading factor value above 0.7 , this indicates that all indicators are valid in measuring the construct so that it can be used in research.

\section{Descriminant Validity}

Discriminant validity was done to ensure that each concept of each latent variable is different from the other variables. The model has good discriminant validity if the AVE squared value of each exogenous construct exceeds the correlation between the construct and the other constructs.

All AVE squared values of each construct exceeds the correlation value between the construct and other constructs, this indicates that the PLS model meets good discriminatory validity requirements. See Table 4.

Table 4. Descriminant Validity

\begin{tabular}{lcccc}
\hline & \multicolumn{1}{c}{$\boldsymbol{O C}$} & $\boldsymbol{E P}$ & $\boldsymbol{T L}$ & $\boldsymbol{W M}$ \\
\hline$O C$ & 0.119 & & & \\
$E P$ & 0.721 & 0.136 & & \\
$T L$ & 0.613 & 0.799 & 0.112 & \\
$W M$ & 0.612 & 0.799 & 0.150 & 0.192 \\
\hline
\end{tabular}

\section{Composite Reliability and Crombach's Alpha}

Construct reliability can be assessed from the value of Crombach Alpha, composite reliability value and the value of Average Variance Extracted (AVE) of each construct. Constructions are said to have high reliability if the Crombach Alpha value exceeds 0.7, the composite reliability value exceeds 0.70 and AVE is above 0.50 .

Based on the reliability test results, the Cronbach alpha value of all constructs $>0.7$, the value of composite reliability $>0.7$ and the AVE value of all constructs $>0.5$ which means that all constructs have fulfilled good construct reliability. See Table 5

Table 5 The Result of Reliability Tests

\begin{tabular}{lcccc}
\hline & $\begin{array}{c}\text { Cronbach's } \\
\text { Alpha }\end{array}$ & rho_A & $\begin{array}{c}\text { Composite } \\
\text { Reliability }\end{array}$ & $\begin{array}{c}\text { Average Variance } \\
\text { Extracted (AVE) }\end{array}$ \\
\hline$O C$ & 0.956 & 0.965 & 0.963 & 0.790 \\
$E P$ & 0.931 & 0.939 & 0.939 & 0.699 \\
$T L$ & 0.903 & 0.910 & 0.933 & 0.771 \\
$W M$ & 0.931 & 0.951 & 0.959 & 0.795 \\
\hline
\end{tabular}

\section{Inner Model (Structural Model)}

\section{Q2 Predictive Relevance}

In PLS analysis, Q2 shows the predictive power of the model. The model value of 0.02 indicates that the model has a weak predictive relevance, the model value of 0.15 indicates the model has moderate predictive relevance and the model value of 0.35 indicates that the model has strong predictive relevance.

The results of the analysis showed that the value of the model Q2 with the performance endogenous variable (EP) was 0.360, this indicates that the full PLS model has strong predictive relevance, as well 
as the Q2 model value with the endogenous variable Organizational Culture was 0.335 which also showed strong predictive relevance and the value of the Q2 model with the endogenous variable of work motivation (MK) was 0.530 which together showed strong predictive relevance. See Table 6.

Table 6. Q2 Predictive Relevance

\begin{tabular}{lrrr}
\hline & \multicolumn{2}{c}{ SSO } & \multicolumn{2}{c}{$\mathbf{Q}^{\mathbf{2}}(=\mathbf{1 - S S E} /$ SSO) } \\
\hline$O C$ & 602.000 & 300.092 & 0.335 \\
$E P$ & 611.000 & 371.613 & 0.360 \\
$T L$ & 333.000 & 333.000 & \\
$W M$ & 516.000 & 232.632 & 0.530 \\
\hline
\end{tabular}

\section{Hypothesis Testing}

\section{Path Analysis}

H1. Transformational Leadership has a positive effect on Organizational Culture.

$H_{01}$ : Transformational Leadership has no effect on Organizational Culture.

$H_{11}$ : Transformational Leadership has effect on Organization Culture.

The result of data analysis (Table 7) $\mathrm{p}$ value $0.000<0.05$ and $\mathrm{t}$ statistic $>1.96$ (significant). So, ${ }_{01}$ rejected, the implication $H_{11}$ can be accepted and original sample (direct effect) was $61.3 \%$ (positive).

H2. Transformational Leadership has positive and significant effect on Work Motivation.

$H_{02}$ : Transformational Leadership has no effect on Work Motivation.

$H_{12}$ : Transformational Leadership has effect on Work Motivation.

The result of data analysis (Table 7) p value $0.000<0.05$ and t statistic $>1.96$ (significant). So, $H_{02}$ rejected, the implication $H_{12}$ can be accepted and original sample (direct effect) was 15\% (positive).

H3. Transformational Leadership has positive and significant effect on Employee Performance.

$H_{03}$ : Transformational Leadership has no effect on Employee Performance.

$H_{13}$ : Transformational Leadership has effect on Employee Performance.

The result of data analysis (Table 7) $\mathrm{p}$ value $0.031<0.05$ and $\mathrm{t}$ statistic $>1.96$ (significant). So, $H_{03}$ rejected, the implication $H_{13}$ can be accepted and original sample (direct effect) was $33.5 \%$ (positive).

H4. Organizational Culture has positive and significant effect on employee performance.

$H_{04}$ : Organizational Culture has no effect on Organizational Culture.

$H_{14}$ : Organizational Culture has effect on Organization Culture.

The result of data analysis (Table 7) p value $0.003<0.05$ and t statistic $>1.96$

(significant). So, $H_{04}$ rejected, the implication $H_{14}$ can be accepted and original sample (direct effect) was $26.3 \%$ (positive).

H5. Work Motivation has positive and significant effect on Employee Performance.

$H_{05}$ : Work Motivation has no effect on Employee Performance.

$H_{15}$ : Work Motivation has effect on Organization Culture. 
The result of data analysis (Table 7) $\mathrm{p}$ value $0.000<0.05$ and $\mathrm{t}$ statistic $>1.96$ (significant). So, $H_{05}$ rejected, the implication $H_{15}$ can be accepted and original sample (direct effect) was $33.3 \%$ (positive).

H6. Organizational Culture is mediating variable between Transformational Leadership and Employee Performance.

$H_{06}$ : Organizational Culture is not mediating variable between Transformational Leadership and Employee Performance

$H_{16}$ : Organizational Culture is mediating variable between Transformational Leadership and Employee Performance.

The result of data analysis (Table 8) p value $0.000<0.05$ and $t$ statistic $>1.96$ (significant). So, $H_{06}$ rejected, the implication $H_{16}$ can be accepted and original sample (indirect effect) was $11.1 \%$ (positive).

H7. Work Motivation is mediating variable between Transformational Leadership and Employee Performance.

$H_{07}$ : Work Motivation is not mediating variable between Transformational Leadership and Employee Performance

$H_{17}$ : Work Motivation is mediating variable between Transformational Leadership and Employee Performance.

The result of data analysis (Table 8) $\mathrm{p}$ value $0.000<0.05$ and $\mathrm{t}$ statistic $>1.96$ (significant). So, $H_{07}$ rejected, the implication $H_{17}$ can be accepted and original sample (indirect effect) was $21.3 \%$ (positive).

Table 7. Path Coefficients (Direct Effect)

\begin{tabular}{lccc}
\hline & Original Sample (O) & $\begin{array}{c}\text { T Statistics } \\
(\mid \mathbf{O} / \text { STDEV|) }\end{array}$ & P Values \\
\hline$O C->E P$ & 0.263 & 2.973 & 0.003 \\
$T L->O C$ & 0.613 & 13.731 & 0.000 \\
$T L->E P$ & 0.335 & 2.161 & 0.031 \\
$T L->W M$ & 0.150 & 29.191 & 0.000 \\
$W M->E P$ & 0.333 & 2.111 & 0.005 \\
\hline
\end{tabular}

Table 8. Indirect Effect

\begin{tabular}{lccc}
\hline & Original Sample (O) & $\begin{array}{l}\text { T Statistics } \\
(|\mathbf{O} / \mathbf{S T D E V}|)\end{array}$ & P Values \\
\hline$T L->O C->E P$ & 0.111 & 2.163 & 0.003 \\
$T L->W M->E P$ & 0.213 & 2.105 & 0.005 \\
\hline
\end{tabular}

Total effect of TL on EP was direct effect plus indirect effect through OC, that was $0.335+0.111=$ 0.446. Total Effect of TL on EP through WM. That was $0.335+0.213=0.548$.

\section{Goodness of Fit Model Test}

The test of the goodness of fit of the PLS model can be seen from the value of the model SMRM. The PLS model is stated to have met the criteria of goodness of fit model if the SRMR value $<0.10$ and the 
model is declared perfect fit if the SRMR value is $<0.01$. The results of the goodness of fit test of the PLS model showed that the SRMR value of the PLS model is 0.012. Because the SRMR model value is below 0.10, the PLS model is declared fit, so it is feasible to use it to test the research hypothesis.

Table 9. The Result of Goodness of Fit Model Test

\begin{tabular}{lcc}
\hline & Saturated Model & Estimated Model \\
\hline SRMR & 0.012 & 0.012 \\
$d_{-} U L S$ & 3.093 & 3.093 \\
$d_{-} G 1$ & 11.057 & 11.057 \\
$d_{-} G 2$ & 9.073 & 9.073 \\
Chi-Square & 7.963 & 7.963 \\
NFI & 0.391 & 0.391 \\
\hline
\end{tabular}

\section{R Square Test}

Interpretation of R Square / adjusted $\mathrm{r}$ square is the same as the interpretation of R Square in the usual regression analysis. The value of $\mathrm{R}$ Square shows the simultaneous influence of exogenous variables on endogenous.

The R Square value can also show the strength of the PLS model, in this case the R Square value of 0.75 indicates the PLS model is strong, R Square of 0.50 indicates the PLS model is moderate and the R Square value of 0.25 indicates the PLS model weak.

Because this PLS model used more than 2 exogenous variables, then the simultaneous effect was seen from the adjusted $r$ square model value. Based on the calculation results of $R$ square in Table 10, there were several results as follows:

i. The adjusted $\mathrm{R}$ square value of the $\mathrm{OC}$ variable was 0.362 , this indicates that the model with endogenous variable organizational culture has predictive power in the moderate category. With this model, $36.2 \%$ variance in organizational culture variables can be explained by transformational leadership variables, while $53.1 \%$ are influenced by other factors outside of transformational leadership.

ii. The adjusted $\mathrm{R}$ square value of the WM variable was 0.719 , this indicates that the model with endogenous variables of work motivation has predictive power in the moderate category. With this model, $71.9 \%$ of the variance of work motivation variables can be explained by transformational leadership variables, while the remaining $21.1 \%$ is influenced by other factors outside of transformational leadership.

iii. The adjusted $\mathrm{R}$ square value of the EP variable was 0.715 , this indicates that the model with endogenous performance variables has predictive power in the moderate category. With this model, $71.5 \%$ of the variance of performance variables can be explained by transformational leadership variables, organizational culture and work motivation, while the other $21.5 \%$ was influenced by other factors beyond transformational leadership, organizational culture and work motivation.

\section{Discussion}

Descriptive analysis showed that the results most of nurses (employee) had high perception toward the transformational leadership. However, leaders should improve their leadership quality particularly on these factors: a) They must have the positive thought to stimulate the employees; $b$ ) They should be the role model for the employees; c) They should motivate the positive thought of employees. 
Nurses perceptions toward organizational culture in this hospital were tend to be good, but still need improvement, especially in the following factors: a. Hospital should be able to position the nurse as an honorable employee / member and pay attention to any decisions that do not harm them; b) the hospital should be able to make the nurse excited to continue to excel and not lazy in the work.

Most nurses had high work motivations, but some of the following factors need to be addressed by the management of the hospital because it can reduce the motivation of nurse work performance: a) Leaders should always appreciate the success of the nurses; b) nurses must be able to complete the task according to the target volume and the allocation of assigned tasks; c) nurses should be able to prioritize work affairs above self-interest; d) The salary received must be in accordance with the workload of the nurse.

The descriptive analysis results show that most nurses have a good performance, nurses have been able to work well either work individually or work in groups.

Transformational leadership had highest path coefficient, $61.3 \%$ effect on organizational culture. To enhance health care and nursing quality and measures leadership styles have essential role. Health care outcomes depend on the different leadership styles, while they may close or broaden the existing gap in health care quality and measure. Talk about gap in health care leadership in environment that change evolutionarily and is challenging, organizations of health care must ensure the professional and technical expertise, capacity building, organizational culture, and balance the priorities of leadership and skills so that indicators of quality in health care can be improved continuously, better than before (Sfantou et al., 2017).

The success or failure of an organization, including a hospital as health care organization is determined by the driving force, that are the phenomena of leadership and organizational culture. A study executed in acute care nursing unit within in a hospital that had excellent organizational performance with consistently of patient satisfaction rating. The data supported that there was contingent level between transformational and transactional leaderships as nurse manager leadership styles. There was association between leadership style and Organizational Culture of nursing unit. They had the ability to stabilize the balance of the dynamics flexibility within their nursing units and maintain the effectiveness of organization that were very essential. The first-line nursing leaders should have competencies, knowledge and skills about organizational cultural (Casida \& Pinto-Zipp, 2007).

Transformational Leadership effect directly on Employee Performance. One of employee performance is productivity of the employee as individual, and the role in team work, and organization. Research of Vatakhan, et al. indicated that to increase employee and organizational productivity, the organization should improve decision making and leadership style lean toward transformational mode. Transformational leadership can be learned. So, training and educational program need essential attention in organization to encourage and develop transformational leadership behaviors which is expected lead employees more productive (Vatankhah et al., 2017).

James MacGregor Burns introduced transformational leadership concept for the first time as leadership expert. Burns stated that transformational leadership can be seen when "leaders and followers make each other to advance to a higher level of moral and motivation." Transformational leaders have strength personality and vision, so that they capable to inspire followers to achieve common goal by changing their perception, motivation, and expectation (Gans \& MD, n.d.).

Transformational leadership has importance role in developing organizational culture, motivating nurses to increase and improve their performance. Transformational leaders have specific characteristic to empower the nurses in a private hospital. Nurse is the most number as health professional in a hospital. They also work in 24 hours and the most frequency contact with the patients, especially in inpatient wards. 


\section{Conclusion}

Transformational leadership influenced nurses (employee) performance, directly and indirectly through organizational culture and work motivation. To improve and maintain employee performance, the hospital should develop nurse competences that are knowledge, skills, attitudes, and behaviors in shaping transformational leadership, develop organizational culture, motivate the employee to involve in providing excellent employee performance. Therefore, special training formally or informally must be planned and done inside or outside workplace. The nurses also necessary give a chance to continue their study to increase the competences and professionalism. For the next research, transformational leadership, organizational culture, work motivation and employee performance need deeply analyze by qualitative approach and experiment method to maximize the benefit of those variables in achieving organizational goals effectively and efficiently.

\section{Acknowledgement}

This research was supported by Universitas Muhammadiyah Yogyakarta.We thank our colleagues from Master of Hospital Management, Postgraduate Program, Universitas Muhammadiyah Yogyakarta and from Rumah Sakit PKU Muhammadiyah Gamping who provided insight and expertise that greatly assisted the research.

\section{References}

Ahmad, F., Abbas, T., Latif, S., \& Rasheed, A. (2014). Impact of Transformational Leadership on Employee Motivation in Telecommunication Sector. Journal of Management Policies and Practices, 2, 15.

Bass, B. M. (1997). Das The Transactional- Tranformational Leadership Paradigm Trancend Organizational and National Bounderies? Retrieved December 17, 2018, from https://home.ubalt.edu/tmitch/642/articles $\% 20$ syllabus/bass $\% 20 \operatorname{trans} \% 201 \mathrm{dr} \% 20 \mathrm{am} \% 20 \mathrm{psy} \% 2$ 01997.pdf

Casida, J. (Jessie), \& Pinto-Zipp, G. (2007). Leadership-Organizational Culture Relationship in Nursing Units of Acute Care Hospitals. NURSING ECONOMIC, 26(1), 11.

Cavazotte, F., Moreno, V., \& Bernardo, J. (2013). Transformational leaders and work performance: the mediating roles of identification and self-efficacy. BAR - Brazilian Administration Review, 10(4), 490-512. https://doi.org/10.1590/S1807-76922013000400007

Gans, S., \& MD. (n.d.). How Do Transformational Leaders Inspire and Motivate Followers? Retrieved December 21, 2018, from https://www.verywellmind.com/what-is-transformational-leadership2795313

Kala'Lembang, A., Soetjipto, B. E., \& Sutrisno. (2015). The effect of transformational leadership and organizational culture on employee's working performance through organizational commitment, $13,5305-5322$.

Orabi, T. G. A. (2016). The Impact of Transformational Leadership Style on Organizational Performance: Evidence from Jordan. International Journal of Human Resource Studies, 6(2), 89-102. https://doi.org/10.5296/ijhrs.v6i2.9427

Prabowo, T. S., Noermijati, N., Faculty of Economics and Business Universitas Brawijaya, \& Irawanto, D. W. (2018). The Influence of Transformational Leadership and Work Motivation on Employee Performance Mediated by Job Satisfaction. Jurnal Aplikasi Manajemen, 16(1), 171178. https://doi.org/10.21776/ub.jam.2018.016.01.20

Sfantou, D., Laliotis, A., Patelarou, A., Sifaki- Pistolla, D., Matalliotakis, M., \& Patelarou, E. (2017). Importance of Leadership Style towards Quality of Care Measures in Healthcare Settings: A Systematic Review. Healthcare, 5(4), 73. https://doi.org/10.3390/healthcare5040073

Syafii, L. I., Thoyib, A., Nimran, U., \& Djumahir. (2015). The Role of Corporate Culture and Employee Motivation as a Mediating Variable of Leadership Style Related with the Employee Performance (Studies in Perum Perhutani). Procedia - Social and Behavioral Sciences, 211, 1142-1147. https://doi.org/10.1016/j.sbspro.2015.11.152 
Tobing, D. S. K., \& Syaiful, M. (2016). The Influence of Transformational Leadershi and Organizational Culture on Work Morivation aand Employee Performance at The State Property Service Office and Auction in East Java Province, 5, 12.

Vatankhah, S., Alirezaei, S., Khosravizadeh, O., Mirbahaeddin, S. E., Alikhani, M., \& Alipanah, M. (2017). Role of transformational leadership on employee productivity of teaching hospitals: using structural equation modeling. Electronic Physician, 9(8), 4978-4984. https://doi.org/10.19082/4978 